\title{
Transnationalism between Galicia and Northern Portugal: An Emerging Cosmopolitism
}

\author{
Xaquín S. Rodríguez Campos \\ University of Santiago de Compostela, Lugo, Spain \\ Email: rodriguezxaquin@gmail.com
}

How to cite this paper: Rodríguez Campos, X. S. (2017). Transnationalism between Galicia and Northern Portugal: An Emerging Cosmopolitism. Sociology Mind, 7, 133-153. https://doi.org/10.4236/sm.2017.74010

Received: July 4, 2017

Accepted: August 21, 2017

Published: August 24, 2017

Copyright $\odot 2017$ by author and Scientific Research Publishing Inc. This work is licensed under the Creative Commons Attribution International License (CC BY 4.0).

http://creativecommons.org/licenses/by/4.0/

\begin{abstract}
This paper deals with the formation of a transnational society between Galicia and the Northern part of Portugal, analysed from an anthropological point of view. Concepts like cosmopolitism, ethnicity, liminality, and memory are central in the theoretical discussion for interpreting the processes of transnationalism. The suppression of the borders in the post-national European Union made the creation of transnational communities near the states' borders possible. This process, in the case of the Galician-Portuguese borders, has developed depending on the ethnic processes, once the Spanish and Portuguese states attained democracies. The concept of a cosmopolitan nation has also been central in the discussion of how ethnicity and nationalism intervene in the process of transnationalism.
\end{abstract}

\section{Keywords}

Ethnicity, Liminality, Memory, Cosmopolitism, Transnationalism

\section{Introduction}

Recent relationships between both societies of Galicia and Northern Portugal constitute a good example of how social spaces belonging to old European borders are reconfiguring, now that the borders between states in the European Union are softer. What I want to propose is an anthropological reflexion for interpreting these social and political realities involved: on the one hand by observing how facts are emerging which favour transnationalities of citizenships and institutions in both countries, on the other by analysing the process of the affirmation of Galician ethnicity in the Spanish state in this context. Here, we recognise two different processes: transnationalism and ethnicity, which can 
sometimes work against each other, but we want to show that they can also be seen as complementary.

The first section of this paper establishes the initial conceptual level; the second examines the transnationalism of institutions and citizens; the third presents an argument for how a historical and symbolic capital imposes its categories of perception upon the bureaucratic field; the fourth section describes the consequences for the transnational market in this regional and transnational area; and finally, in the fifth section, I discuss the topic of a cosmopolitan nation as an organisation of cultural pluralism in the transnational world.

\section{Transnationalism and Liminality for Reconfiguring Both Countries}

In 1994 the Schengen agreements were signed and the European borders within the European Union disappeared, but the memory of medieval heritage, which symbolised the borders of both regions, Galicia and Northern Portugal, live on through their impressive fortresses in the border towns of Valença do Minho, Chaves, Bragança, Tuy, Verín. These fortresses were built during medieval wars for the political hegemony between the archbishops of Braga and Santiago de Compostela, but today evoke a memory of the past. This memory persists through its process of renovation despite the passage of time. The novelist Saramago (2002: 85) in a very famous Portuguese travel guide, when he contemplates the old downtown of Braga he imagined that the city was built in medieval times, all the while looking towards the city of Santiago de Compostela for inspiration when it was the epicentre of Christianity in the Iberian Peninsula. It was as if they were contemplating this town as its future, "instead of looking to the rest of Portugal". Saramago said that it was an idea which had just passed through his mind, in an inspired moment. This was not a remembrance of the past but an imagination created in the present by looking at Braga's cultural heritage, which, suddenly, was receiving more popular vitality by looking to Galicia, and the tradition of the St. James' Way, after supressing the borders of both states. In this new context, Galicia was also represented, for a few informants, as a field which promised new opportunities and imaginations for people from the North of Portugal.

Liminality was the concept proposed in Turner's (1969: 138) work by describing the ritual process that would form an essential community from the "spontaneous communitas", which emerges in spontaneous liminal situations. At the Galician-Portugal borders, during most of the twentieth century, the dictatorships of Salazar in Portugal and of Franco in Spain established agreements after 1936 to capture exiles who escaped from their respective regimes. The Galician-Portuguese borders were rural lands in which there existed an increased solidarity in favour of hiding neighbours pursued by the policies which sought national revenge against the exiled. Anthropologists, Martins (2008: 142) and Godinho (2011: 457), hint at popular narratives of the risky popular solidarities ex- 
perienced on the Portuguese border.

Galician writer Mendez Ferrin (1991), and Portuguese writer Da Cruz (1980) both released very successful novels reliving the events between 1936 and 1970 . Both narrated, in very different styles, popular memories of historical events that occurred between the aforementioned dates, during the times when firm borders still existed and were guarded. They wanted to portray the Galician-Portuguese character at the border. It is surprising that the magical world, which Ferrín details about the Galician border, could be seen from the other side as described by $\mathrm{Da}$ Cruz, in a more realist picture, by portraying similar contexts into a shared cross-border adventure. The strong dependence among people who lived on both sides of the borders made living separated lives impossible.

The events narrated by both classical narratives serve to rebuild in democracy the memory of the "spontaneous communitas" at the borders in the past around the liminal figures of the exiled pursued by both dictatorships and who were also very known members of families from small border hamlets. When the borders had been transformed-once democracy and the EU were constituted-into administrative boundaries, this began to promote the processes of transnationality: the memories of the exiled had been converted into liminal and dramatically historical figures for the creation of the Galician-Portugue see ssential community. What I propose here is that although a "spontaneous communitas" existed before at the borders of Galicia and the North of Portugal, the new processes generated by transnationalism have been intervened by these liminal memories, whose monuments continue today to reinforce and renew common cultural ethos, promoting a transnational community once was constituted the European Union.

The transformation of Galicia and the Northern of Portugal regions into a transnational community is clearer every year from a variety of activities organised in different places in both countries: some examples being the cooperation of Galician and Portuguese universities, congresses, familial and professional celebrations in one another's countries, gastronomic and ecological popular fairs and festivals, very frequent musical events, the emergence of citizen associations for mutual cooperation, and the origins of new common institutions, which I will discuss later. The Portugal-Santiago de Compostela pilgrimage route-named The Portuguese Way-is more active every year. It was discovered and promoted in the final decade of the twentieth century. Everyday goods are becoming very popular amongst many people living near the border, which explains the appeal of popular fairs and festivals in both countries so as to enjoy the gastronomy, buy handicrafts, domestic technology, clothes, and hear popular music. Some of these objects maintain their attractiveness due in part to the liminal national memories they evoke in popular culture, which is also being shared in popular memory on the other side of the border as part of their respective national memories, which generate cultural mimesis between both countries.

In the past, when the borders were firm, there existed a common life amongst 
Galician and Portuguese people along the borders but it was a common life marked by neighbour cooperation in marginal activities, like smuggling, hiding the exiled, tax avoidance from one state to the other, and moving to the more convenient area for work. All of these things are mentioned in the works of Kavanagh (1994; 2011), Godinho (1995: 216; 2008: 222) and Afonso (2003), amongst others. Similar descriptions were written by Douglass (1998; 1999) about the border experiences people lived in the Pyrenees amongst Spanish and French people, and by Valcuence del Rio (1998: 132) amongst Portuguese and Andalusian people in the South of Spain and Portugal. Godinho (2011:244) and Afonso (2003: 37) also describe adventures and risks shared between people on both sides of the border as well as living in strong solidarity attained through smuggling activities. Living temporarily in local hamlets on both sides of the Spanish-Portuguese and Spanish-French borders was a common occurrence, first, to keep away from the surveillance of civil and military authorities: it was a favoured method of creating a normal life and it required a sense of permissiveness and cooperation amongst neighbours who were separated by national borders; second, when the Inquisition was instituted in Spain, in France, and in Portugal, later as a consequence of the French Revolution, and third under the dictatorships in Spain and in Portugal.

This social and political context in the past increased solidarities at the border, but it does not explain the construction of a Galician-Portuguese transnational community later when Europeans had been constructing the European Union. I think that this new emerging context can be explained first, by the existence of an essential community along the borders, which today continues to be renewed through the memory of past, second, by the mimesis created by cultural affinities amongst both Galician and Portuguese communities, and third, by the new political and institutional opportunities which emerged from the construction of the European Union.

Renewed perspectives have been appointed by studying the transformation of historical frontiers into borders between Spain and France, Portugal and France. Pujadas, Comas, Moncusi, \& Martinez (1999: 152) insisted on affirming the process of increasing national differences in two Spanish and French border towns-the two Cerdanias-in the Catalan Pyrenees during the 20th century. The classical study by Sahlins (1989: 275) in both the French and Spanish Cerdanias, also insisted on the affirmation of French and Spanish national identities on the borders because of how the French Revolution had marked differences in both national cultures. Roigéi (2006: 49) insisted on the same idea by pointing out how Spanish tourism had contributed to the local development of the whole Spanish and French region. On the Spanish-French Basque border, Douglass (1998: 90; 1999: 19) signalised the full historical cooperation and solidarity amongst Basque people of both states by considering the political differences between Spanish and French national cultures to be less important.

Some approaches suggested the problems involved in dealing with the rela- 
tionships on Portuguese and Spanish borders came after the constitution of the EU. Valcuence del Río (1998: 125), pointed out that as the Spanish state had developed the regional governments (The Spanish State of Autonomies), which have augmented the municipalities and regional political preoccupations for the relationships on the Portuguese borders because of new opportunities created by the EU but, in contradiction, he comments that popular concern has decreased for the traditional Andalusian interest in life on the Portuguese border. Medeiros (2013: 352), dealing with the Galician-Portuguese border, has been writing a personal position on the question of how Galician and Portuguese people imagine each other in positive ways. By recognising the tradition of ambiguous characterisation of the other, as a result of historical borders, Medeiros pointed out that the Galician nationalist movements have been recently promoting positive images of the Portuguese character, which can be perceived in the whole society of Galicia, and which contrast with the traditional contempt. A similar idea was defended by Douglass (1998: 96), pointing out how the Basque ethnic identity served to promote the solidarity amongst the Basque people instead of the division by the French-Spanish national borders. I want to explore both ideas in this paper, by explaining that the process of Galician-Portuguese transnationalism has its ethnic roots, especially in Galicia, which allow us to understand the current economic and political processes.

The administrative boundaries between Galicia and Portugal, which substitute the old borders, have also been relaxed due to favouring transnationalism. It is possible today to obtain dual nationality for citizens of both Spanish and Portuguese states. In Spain, the laws pay more attention to the Portuguese and some other citizens from the Americas because of their own historical relationships. The new Civil Code approved in Spain in 1982 did specifically allow Portuguese citizens and some from various Latin-American countries to obtain dual nationality by residing in Spain for just two years. For citizens from other countries, however, Spanish laws require ten years of permanent residence. In Portugal, there are no laws that recognise dual nationality for certain countries over others. The Law of Nationality from 1994 establishes dual nationality for foreigners who get married to Portuguese citizens and maintain their vows for three years, or for those with permanent residence in Portugal for six years. As a consequence of this, in 2012, about 22,797 Portuguese citizens resided in Galicia, and in the entirety of Portugal there were only 10,486 Spanish citizens in 2011; only 1128 Spanish citizens reside permanently in the North of Portugal. The laws do not explain transnational population movements, especially movements that occur every day across the countries' borders, but show that Spanish legislation takes Portuguese immigration into account because of transnational immigration, and, as a result, favours this movement. They have increased the opportunities for attaining dual nationality in Spain, which favours Portuguese immigration into Galicia. Portuguese immigrants are now the largest foreign nationality present in Galicia and this has been the case for many years and is contributing to a process 
of transnational miscegenation.

\section{Transnationalism of Institutions and Citizenships}

Recently, more complex forms of cooperation amongst the regions of Galicia and the North of Portugal have taken place-forms never imagined in past. The nation-states crisis in Europe has brought about the process of decentralisation of the state in Spain, which has contributed to the reinforcement of ethnic identities competing amongst themselves for national services and resources. As put by Moreno (1991: 605) in a classical work, the process of decentralisation could be defined as a cultural reinforcement of ethnic identities with the movement of political nationalism in all regions of the Spanish state, looking at ethnicity as the structural concept for defining a nation, which must defend its cultural identity and limits against others. It did not occur in the case of the Portuguese, in which a state national identity persists, although an ethnic division between the north and the south also persists, like a historical affirmation of cultural and political differences between them as a political consequence of The Revolution of April 25 in 1974, as recognised by Cabral (1992: 695) and by Sobral (2008: 207), amongst other Portuguese historians and anthropologists. In this case, we are talking about the affirmation of ethnic identities because of the state's process of democratisation in Portugal, just like what has happened in Spain with more institutional consequences for the state's organisation.

This said, the political differences between Spain and Portugal in the development of democracy did not prevent the conversion of Portuguese national borders to Galicia into cultural limits, which have promoted transnationalism. As recognised by Barth (1969: 18) in his classical work, complementary cultural features of ethnic groups, like native languages, favour the interdependence or symbiosis between them-by urging them to attend to the dynamics of ethnic boundaries against static objectivism, as pointed out by Brubaker (2009: 29). This hypothesis can to be applied to the Galician-Portuguese process of transnationality. On the one hand, Galician nationalism movements are promoting transnationalism to Portugal because of its ethnic interdependence. On the other, today, some states belonging to the EU find different forms of transnational and territorial associations, like in the cases of the Euroregion's projects, promoted by the EU and demanded by states like Spain, Portugal, France, and Belgium, and, in the case of Galicia and the North of Portugal brought about the organisation of a Euroregion in 2008.

From an anthropological point of view, we can ask if one affective concept of culture would be possible, which could go beyond the culture experienced within the nation-state. It all depends on how we understand the concept of culture, in the static sense, it can be defined as a system of symbols and values shared only in a society. In this case, little space can remain beyond the concept of culture understood as a national culture. In the Radcliffe-Brown's (1958: 62) work, culture was already understood as a dynamic that joined individuals and different 
groups into a stable and complex structure, which make possible the organisation of an orderly life in which every culture has to accept interdependence on others. As Kuper (1999: xiv) comments, Radcliff-Brown has taken his experience from the Apartheid in South Africa, when he was the first professor of social anthropology there, and what he wanted was to escape from the definition of culture as an abstraction for sacralising social differences, because the national institutions crossed all cultural borders. A society composed by many ethnic groups needed to share values and symbols in the process of its interdependence. In the context of the EU, beyond the existence of national culture in every state, above ethnic differences, we can appreciate the existence of transnational communities at the borders that want to affirm common symbols, values, institutions, and activities. Are Galician citizens only worried about what happens in Galicia and in Spain, or is what happens in the North of Portugal an important issue for them, too? And vice versa?

We can understand, in this sense, the existence of a Galician-Portuguese transnational community, beyond the borders of both the Spanish and Portuguese states. A transnational community is, in this sense, a community of citizens who want to affirm their social and political solidarities over their ethnic and national ascriptions, as defined by Appadurai (1996: 147), a movement which operates beyond the confines of single nation-state, by mobilising national ethnicities (Appadurai 1996: 147). In other contexts, a transnational community was defined as a community made up of individuals and groups that are established within different national societies, and who use networks to strengthen their solidarity beyond national borders (Kastoriano 2000: 353). However, could effective instruments for solidarity beyond the organisation of the Portuguese and Spanish states be created?

The constitution of the Galicia-North Portugal Euroregion took on various projects in different moments. It was legally approved in September of 2010 as a macro-region by the EU, named RESOE (Macro-region of Regions of South-Western Europe), formed by Galicia, North Portugal, and Castile-Leon, and enlarged in 2014 by including the Spanish region of Asturias, and the central region of Portugal, celebrated with gatherings in the cities of Vigo, Porto and Coimbra. However, up to now only the organisations created by the Galician government (Xunta de Galicia) and the Portuguese Comissão de Coordenassão da Região do Norte, named GNP-AECT, and founded in 2008 in the Galician city of Vigo have been effective. Both Galicia and Northern Portugal's interest in the creation of common development projects goes back to 1979 in the first meeting celebrated between the representatives of both regions' governments. The first association, named Comunidade de Traballo Galicia-Norte de Portugal (Galician-Northern Portugal Labour Community) was constituted in 1991 after the official constitution of the autonomous governments by the Spanish state and was approved by the Regional Policy of the EU, considering a territorial joint articulation "for connecting to the high networks of communication in 
Europe".

More popular initiatives were launched in 1992 with the meeting of the mayors of the 18 main cities and towns of Galicia and Northern Portugal, which constituted the Eixo Atlántico do Noroeste Peninsular association, with the magazine Economía Atlántica, which is still alive and well and remains very important today. This association was also interested in the creation of gastronomic festivities, the promotion of fairs, and cultural events in the border cities and towns for promoting more joint Galician-Portuguese activities. The consequences were more popular affluence to the fairs and local festivities and more popular activities in Galician towns like Verín, Xinzo, Salvatierra, and Tuy, and in the Portuguese Valença, Monção, Barcelos, and Chaves.

The Eixo Atlántico association would later integrate into the Comunidade de Traballo Galicia-Norte de Portugal (Pardellas, 2006: 207), by revealing the joint popular interest for promoting local development and taking into account any networks for the coordination of both regions. It took place in 2002 at the Centro de Estudos da Eurorregión (the Euroregion's Centre of Studies), organised by the universities from both regions (Santiago, Vigo, Coruña, Porto Braga, Barcelos), which, in the same year, organised the first exchange programme for students of Galicia and the North of Portugal and which has since been repeated every year. The event considered to be the most successful from all the efforts pulled together for the coordination of both regions was the construction of the motorway from Lisbon to Ferrol so as to bring the towns of Valença and Tuy together, the inhabitants of which celebrated this event at two festivals in both towns in August of 1998 when the road was finished.

The event considered the second biggest was the creation of GNPT-AECT in 2008. This institution has been organising many initiatives, a statistic yearbook about the Euroregion from 2010, business cooperation programmes especially in the food, textile, and timber sectors, they have already offered four Iacobusex change programmes for researchers, students and management staff at universities with an ambitious investment programme for 2020. Amongst these projects on the agenda, there is a Eurocity between the towns of Verín (Galicia) and Chaves (Portugal), conceived through the promotion of thermal tourism, the common management of the Gerés (Portugal) and Xurés (Galicia) national parks-both on the borders of their respective countries-through a tourist programme, and also the more ambitious project of a common Galician and Portuguese cultural industry.

In March of 1995 two bridges were inaugurated to connect the border towns of Monção (Portugal) and Salvatierra (Galicia) via a dual carriageway. Sixteen Galician and Northern Portuguese primary schools celebrated this event with a radio broadcast lasting twelve hours. That is how the radio program named "Ponte nasondas!" came to be, broadcasted in both Galician and Portuguese languages and which lives on today. Music, songs, stories, and interviews occupied these programmes, which, in the words of a Portuguese woman teacher who answered the question asked on air: What can you do for bettering the rela- 
tions among both Galician and Portuguese people? The radio programme was transmitted every year on the same days of celebration, and every year more Galician and Portuguese schools were incorporated into it, and even a few from France and Brazil in 1999, attaining the number of fifty schools and more than 700 students. The initiative began in Monção and Salvatierra, but has been extended to Melgaço, Montalegre, Vila-Real and Vilanova de Cerveira in Portugal, and to Allariz, Tuy, Salvatiarra, Ourense and Vigo in Galicia and then diverted to other schools and towns. Teachers, students, and well-known Portuguese and Galician singers have all participated.

Since 2001 this popular initiative has been converted into a cultural movement for promoting the intangible heritage of the Galician-Portuguese border, discovering via the programme the diffusion of cultural material sat tained from collaborators. Many schools from both countries participated in the ethnographic collection of traditional oral materials, and, in 2004, this movement presented a Galician and Northern Portuguese application for declaring this movement a movement in favour of the promotion of the Galician-Portuguese intangible heritage of UNESCO. That said, the most important thing was the work completed by the teachers and students of that generation in both countries. They performed said work to each other over radio broadcasts, narrating stories, oral poetry, and local traditions unknown before. Every child sings and narrates in their own languages, but everybody understands each other due to linguistic similarities.

In November 2002, the Prestige catastrophe took place which resulted in thousands of tonnes of oil being spilled into the sea and which affected many Galician estuaries. The radio broadcast "Ponte nasOndas!" dedicated the next two years to becoming a platform for raising awareness about the issues of living on the seashore. In 2003 and 2004, a lot of buses came from the North of Portugal throughout the year carrying with them numerous scholars and young people to work on the Galician beach cleaning initiative.

The cultural and educative movement "Ponte nasOndas!" has to be understood as a movement that has given rise to the Galician-Portuguese cultural miscegenation, the spontaneous call for building the essential community, due to the current worries about the Galician-Portuguese border's cultural heritage, always very attentive to the social problems which demand solidarity for collaborating in moments and places in every country. But this movement did not come about by chance. It emerged from an essential community that promotes the recovery of ethnic memory in both countries.

Institutional and cultural initiatives and their effects on the Galician-Portuguese transnational flux should be understood as a process of constituting a common citizenship. Could we see a similar political Spanish-Portuguese convergence and a common interest at other Spanish-Portuguese national borders, like those of Castile, Extremadura, or Andalusia? Absolutely not. Why did the official macro-region that also included Castile \& Leon and Asturias not operate until now? The explanation would be that between Galicia and the North of Portugal an es- 
sential community already existed due to linguistic and cultural affinities, which were historically affirmed. Although cultural affinities do not develop political wishes by themselves, they are necessary for being expressed. Cultural affinities are not sufficient alone to form political wishes: there needs to be other cultural mediations, as we will see in the next section.

\section{The Historical Identity among Galicia and the Northern of Portugal}

This transnational flux which we have come to remark can only be understood from the symbolic capital, as has been defined by Bourdieu (1998: 194), the symbolic capital which imposes its categories of perception upon the bureaucratic field, and the symbolic capital which exhibits on economics Bourdieu (1990: 204) - as we will see on the next section. The memory recovered from border solidarities and adventures in the past and lived in the present. Linguistic affinities are also very important, because they have promoted cultural roots in the ethnic community. Every day, linguistic codes from the Galician language are more and more like the ones from Portuguese. Northern Portuguese people are defined as "Galician" by the Southerners because of the higher number of linguistic affinities with the Galician language they have.

On the other hand, there is an old vindication from Galician and Portuguese intellectuals and artists who, the nineteenth century, tried to express the need to form a transnational community through the ethnic affinities amongst both peoples. This vindication was corroborated by the nationalist movement in Galicia from the Galician side, historians who founded the regionalist movement in the 19 thcentury, like Manuel Murguía, have talked about the Galician and Portuguese common nation, which was dramatically cleaved, as remarks Beramendi (2008: 20), in the context of a racial vision of culture, which considered that Galician and Portuguese people were the same race like defended Risco (1920: 7). Rodríguez Castelao (1976: 328), one of the most prominent representatives of the Galician nationalist movement at the beginnings of the 20th century, considered the racist nationalism as a "delirium" and an historical "sin". He considered that the Galician and Portuguese were "the same ethnic people", by comparting their same genius creator which came from the same "mother-earth" - the root metaphor of the common ethnic origins for Galician and Portuguese people. Like a few Portuguese historians and philosophers of the same generation, he considered Galician and Portuguese people as two brothers separated by the arbitrariness of medieval political events Rodríguez Castelao (1976: 335). But both people were, in his view, a mixture of races, and not pure ones. His nationalist view defended the integration of Portugal into an Iberian federation because his vision of nationalism was federalism, not independent states.

From the Portuguese side, the poet Teixeira de Pascoaes, one of leaders of the "renascence portuguesa" (Portuguese Renaissance) movement published a few works with Galician nationalists, and he talked about the Galician and Portuguese common motherland ("alma patria"), which was "much unknown to the Portu- 
guese people" (Barreiro Barreiro, 2016: 27). Race was not the common argument of this Portuguese movement, although Pascoaes (1998: 13, 97) defended a common Galician-Portuguese race which constituted the "nation that wanders" through strange lands, showing its own natural force, prone to both adventure and nostalgia- “saudade". Most Portuguese intellectuals of this generation defended that the Portuguese people were a mixture of races, like the Galician Castelao, a shared idea amongst Jorge Dias, Francisco Da Cunha Leão, and Fernando Pessoa, who considered the Portuguese people as a cosmopolitan people, and the mixture of races which facilitated its capacity to mix with other people. The Northern philosopher, Leão (1973: 117), in his work “enigma portugués” defended eleven psychological features, which differed between the Castilian and the Portuguese character, into an analysis which would to demonstrate strong differences throughout history. However, it determined that the Portuguese and Galician character were, in fact, the same, as Pascoaes defended. See also Pinto (2007: 21).

The Portuguese historian, Lourenço (1988: 19), asked how the similarities between the Portuguese and the Galician character-so independent and affirmed as ethnographer Jorge Dias defended-cannot explain why Galician people did not gain independence from the Spanish state. He defended the same argument defended by Castelao many years ago to explain this historical contradiction, the historical arbitrariness of the medieval world, the fratricidal struggles which divided the two brothers.

Galicia took part in the collective imagination of these Portuguese intellectuals, because it was the other face of the Portuguese Minho River region, which they considered the "sacred tabernacle" of the Portuguese ethnicity, as signalled Medeiros (2013: 278). This Portuguese and Galician narrative about the same Portuguese and Galician character, composed a cultural memory of a common ethnicity in both countries, which served to enlighten many people about the existence of this common ethnicity in the beginnings of democracy, where discourses on ethnicity proliferate both in Galicia and Portugal.

Reflections about the common Galician-Portuguese identity created common cultural movements, like "Ponte nasOndas!", which brings the Galician and Northern Portuguese peoples together to a greater extent than other Portuguese and Spanish people. There are not only solidarities that lived in the past but also the cultural field composed of rebuilding memories, historical reflections, and monuments which promote liminal symbols experienced very differently in past and present. It constitutes the cultural field which influences the political and economic field by creating a transnational community.

\section{The Transnationality of the Market}

Table 1 shows the changes in the principal municipalities on the border of Galicia and Northern Portugal.

Although the Portuguese border municipalities have a higher population than their Galician neighbours, in the 20 years between 1991 and 2011-the years of the European free market-the Galician border municipalities increased at the 
Table 1. Population of municipalities on the Galician and Portuguese border.

\begin{tabular}{cccccc}
\hline Galicia & Tuy & Verín & Xinzo & Salvatierra & Total \\
\hline 1991 & 15.242 & 11.279 & 9.170 & 8.915 & 44.646 \\
2011 & 17.230 & 14.633 & 10.311 & 9.542 & 51.716 \\
\hline Portugal & Valença & Chaves & Melgaço & Monção & \\
\hline 1991 & 14.815 & 40.940 & 11.019 & 21.799 & 88.543 \\
2011 & 14.127 & 41.243 & 9.213 & 19.230 & 83.813 \\
\hline
\end{tabular}

expense of the Portuguese ones, which lost more than 7000 people during this period in which Northern Portugal increased its total population by $3 \%$, instead, the general Galician population increased by $2.3 \%$. This population transfer can be explained as a result of better work opportunities, as has suggested Godinho (2008: 227).

The transnational transfer of populations from Portugal to Galicia was greater than to any other Spanish Autonomous Communities. In 1999, 30, 996 Portuguese people were in Spain according to the data from the INE (the National Institute of Statistics), 7243 of them resided in Galicia (23.3\%). The most recent data, from 2012, reports that there are 22,797 Portuguese residents in Galicia, predominantly people between the ages of 35 and 45 with few qualifications-most have only primary studies. This means that $22.3 \%$ of all Portuguese people in Spain reside in Galicia. This percentage is greater than in other Spanish regions, included Madrid, which has the largest economy in Spain. These figures show that the Portuguese working class prefer Galicia to all other Spanish regions, despite the fact that its economy is less dynamic than others.

Paying attention to the foreign market data taken from AECT Galicia's databases-Northern Portugal played an important role in unifying the power of the Galician-Portuguese market in 1993. The export of goods from Galicia to Portugal went from $€ 362.2 \mathrm{~m}$ to over $€ 2.49$ bn in 2010. The Portuguese exports to Galicia went from $€ 201.3 \mathrm{~m}$ in 1993 to over $€ 2.12 \mathrm{bn}$ in 2007 - the year with the greatest growth. Other significant data determines that in the year $200423.2 \%$ of exports from the North of Portugal to Spain went to Galicia-this region being only $6.7 \%$ of the entire Spanish population. In 2005, Galicia imported $57 \%$ of the milk Portugal exported to Spain, which demonstrates the high preference for Portuguese products in the Galician market. In 2004, the entire market value between Galicia and Northern Portugal was $€ 1.48$ bn, constituting a similar market value that the Portuguese maintained with Italy, Great Britain, or the Netherlands.

There is no doubt about the increased market size between Galicia and the North of Portugal after the disappearance of the borders. The most important export sectors from Galicia to the North of Portugal were agriculture, fishing, and food, followed by the textile sector. Galicia exported $33.9 \%$ of its food production to Portugal in 2011,35\% of its fishing production in 2001, $71 \%$ of its meat production in 2005 , and $22 \%$ of its textile production in 2010. In the fur- 
niture sector, Portugal was the main provider to Galicia with $57 \%$ of its importation.

This macroeconomic data does not show the importance of the popular fairs in the border areas in Portuguese towns like Chaves, Melgaço, Monção and Valença, and the Spanish towns of Verín, Xinzo, Salvatierra and Tuy. These fairs can be every week, every 15 days, or every month, in addition to gastronomic and ecologic fairs to attract Galician and Portuguese tourism. These fairs affect the opportunities of transnational workers as well as small and medium businesses motivating them to offshore from one side of the border to the other, as well as to form alliances and create strategies with businesses on the other side, as economists Diniz \& Gerry (2008: 161) have pointed out.

This transnationality in trade, as we have already mentioned, is not so prominent for other Spanish-Portuguese borders, like Andalusia, Extremadura, or Castile. In a recent study, Falagan, De Carlos, \& Lorenzo (2013: 85) show that $50.3 \%$ of the road traffic between Spain and Portugal from 2004 drives through the Galician and the Northern Portuguese borders. $87.8 \%$ of this traffic is made up of tourists, and the rest were workers. Approximately, about one million of these travellers did overnight stays of more than one- and less than two-days in Portugal, and did more than two- and less than three-days in Galicia. The intensity of this traffic is greater from the North of Portugal to Galicia than vice versa. The North of Portugal has a higher population than Galicia; the former has 3.7 $\mathrm{m}$ people, and the latter $2.7 \mathrm{~m}$.

It is not so easy to understand why the Galician market has a greater demand for Portuguese goods, only in economic terms, nor why Northern Portuguese workers prefer to work in Galicia, because in absolute numbers the Galician market holds greater importance for them than other more dynamic economies like Andalusia, Madrid, the Basque Country, or Valencia. The Galician informants experience a greater attraction for Portuguese wines, oils, the regional gastronomy, and the autochthonous furniture. The Portuguese informants experience a greater attraction for Galician meat, conserves, dry cod, and cultural activities in Galician towns in the summer. Informants of both countries thoroughly enjoy musical groups from each other's countries: groups which would pass through Galicia and Northern Portugal every summer. I think that objects-tangible or not of consumerism can also be interpreted as liminal symbols for the ethnic common memory, which intervenes in the Galician and Portuguese transnationality.

An ethnographic example of how objects of consumerism have been intervening as liminal symbols, for the creation of the common memory is the case of "alheira" of Tras-Os-Montes. "Alheira" is a traditional sausage made of bread dipped in sauce with poultry and lamb, which after is subjected to a smoking process, usually in households. This tradition goes back-like they say in Tras-Os-Montes-to when the Spanish Catholic Kings threatened in medieval times to impose the expulsion of the Jews from Portugal on the Portuguese kings as a condition for accepting to marry one of their daughters to the prince of 
Portugal. The Portuguese kings did not want to exile all their Jews. The Jews invented the "alheira", which would hang in households to be smoked, like the pork sausages-though it did not contain any pork. So, the Portuguese Jews demonstrated that they ate pork, and as a means of displaying that they were no longer Jews. The "alheira" is eaten accompanied by traditional vegetables, such as greens and potatoes, also very typical in traditional Galician Stew. For the moment, it only appeals to the Galician informants and not to the rest of the Spanish, which I know because they are not so keen on Galician Stew.

"Alheira" also began to be consumed-but not made-in Galicia at some point in the past fifteen years, but not before. It is important not for the qualities of the product but rather because of the Portuguese narrative, which awakens in Galician people common national memories, and which promotes common ethnic customs for cooking in Galician and Portuguese rural and urban areas.

Cod fish also constitutes another wonderful symbol in the cultural history of Galicia and Portugal, because of its representation in the Catholic tradition of the Southern Europe. The salat cod was an essential food for feeding the Catholic population for half of the year in the 19th and 20th centuries, when people could not eat flesh on "lean days", during Lent, and the rest of the Fridays per year. Given the lack of access to other cheap foods for obtaining proteins, as put Kurlansky (1998: 135) it has become a religious icon for the Catholic tradition. After the Civil War of 1936 the salat cod was also a cheap fish distributed thanks to the Spanish policy for feeding the population, known as "racionamiento" (rationing in times of shortage). Galician people would prepare it by just boiling it. During the 40s, 50s, and 60s of the 20th century, all over Galicia cod fish was the food for the poorest people, rejected by the remaining social classes for being an icon of the past marked by the culture of hunger. Only after the 70 s, when the Galician population began to drive to Portugal, once they reached the purchasing power required for having cars, they learned from the Portuguese middle class how to cook cod fish in different ways, giving it rich flavours. Once they began to appreciate the Portuguese cooking and their pristine and ethnic purity, Galician people began to appreciate the cod fish, by introducing it progressively into their diet. The old taboo surrounding it was suppressed through the appreciation of Portuguese cooking and because of their reflexion about the common ethnicity in the post-modernity époque.

\section{The Cosmopolitan Nations}

The process from the existence of transnational communities at the borders of states to more cosmopolitan nations, which recognise the rights of being cosmopolitan citizens, could be inescapable and irreversible, just like Hannerz (2006: 18) proposed. The concept of a "cosmopolitan nation" was presented by Giddens (1998: 130), although the concept of a "cosmopolitan democracy" was established earlier by Held (1995); Archibugi \& Held (2011), and then by Habermas (2006). What these European thinkers proposed could be defined as the 
end of the absolutism of national sovereignties, under the pressures of the global citizenships, which puts restrictions on the national state for the creation of a transnational democracy. The principal problem is how to constitute a cosmopolitan nation, which consists of not only common institutions supported by the national sovereignties, but also a sense of common cultural belonging from the national citizens. Cosmopolitan nations, in the sense of Giddens, like ethical communities who defend cultural pluralism, should be capable for integrating ethnic identities by recognising their respective rights, and the individual rights of citizens. A cosmopolitan nation then presupposes the existence of a citizenship which demands the rights to ethnic difference in the current process of globalising national citizenships. Because the world culture "is marked by an organisation of diversity rather than a replication of uniformity", as insisted Hannerz (1990: 237). Shweder (2010: 222), in pointing out the need to be "a robust cultural pluralist and dedicated political liberal at the same time", he has proposed theories of political pluralism based on principles of divided sovereignty, limited government, and the dispersion of power to the future of democracy.

We have just seen before that the process of Galician-Portuguese transnationalism has been creating new forms of ethnic communities which demand cultural activities and rights in their own states. For example, the rights to a common memory and heritage that demands common cultural rights for being recognised as an ethnic community, who demands global institutions and governance.

The discovery of the "Portuguese Way to Santiago" ("Camino portugués"), as a Portuguese route of pilgrimage to Santiago de Compostela, before the holy year of 1999, was the official acknowledgement of a historical route for the Portuguese and Galician common cultural heritage, which connected the cities of Braga and Santiago de Compostela. It was a consequence of the Galician cultural policies to integrate itself into Europe (Méndez, 2004; Rodríguez Campos, 2004), but it promoted tourism and also the image of a common Northern Portuguese and Galician ethnic belonging. My Portuguese informants from Tras-Os-Montes (in the north), who were all teachers at primary and secondary schools, and their families expressed a sense of ethnic belonging between 2003 and 2008. Two of them completed the pilgrimage to Santiago and to Fatima in the same year, as per their religious commitment. But the remaining twelve of them, who had never been to Fatima, went every year to Santiago to visit the city and to attend musical, cultural, or political events. They were very interested in observing the historical links between Braga and Santiago in the medieval times, through the cultural heritage present in Santiago. With their observations, they defended the presence of their own Portuguese national memory in Santiago; but at the same time also affirmed their ethnic sense of belonging to the common memory of the city's heritage, which, in a cultural sense, does pertain to them, like the "Portuguese Way to Santiago". Once St. James' Way's cultural heritage was given World Heritage status by UNESCO in 1985, citizens from anywhere in the world 
could demand their rights to its preservation-not only Galician or Spanish people.

An interesting observation was made by the anthropologist Medeiros (2001: 244) who, whilst in Santiago's city centre, had an encounter with a group of Portuguese people and a group of young Galician nationalist students. The Portuguese group was headed by their priest near the cathedral he was visiting. The Galician students broke into song, singing in Galician "long live the Galician and Portuguese common republic". The Portuguese group, which belonged to a rural area, was very surprised, talking amongst themselves about how these young students were crazy. This case shows that the frequent encounters between Galician and Portuguese people on their way to Santiago are always charged by profound affectivity, because of the popular sense of a common belonging. But it also shows that the pilgrimage is for some Portuguese and Galician people a liminal space of intersection-in the sense of Turner-of two different national memories. The memory of the religious pilgrimage and the memory of a common ethnic belonging can sometimes be separated or connected between them. These intersections of memories into the Galician and Portuguese cultural spaces are very frequent.

In the years 2007 and 2008 I attended several congresses organised in Galicia and in the North of Portugal to reflect on culture, heritage and development in order to think about the perspectives of the Galician-Portuguese Euroregion, which had been proposed to the EU. The first event, which was celebrated in December 2007 at Chaves-when the political proposal in favour of the Euroregion was presented-was also the most dynamic. From a Portuguese perspective, only one participant expressed his worries faced with the risk of the ethnic essentialisms which could appear because of the proposed Euroregion. Other Portuguese participants expressed better perspectives before the process of transnationalism for both regions. The Galician participants, more accustomed to reflecting on ethnic identities and nationalisms, mostly insisted on the need for creating the Euroregion as a bureaucratic sphere for promoting common culture, cooperation and development and yet do not eliminate the already existing national spheres. One of the Portuguese organisers of the event highlighted in his conclusion that we, the Galician and Portuguese people, are now "learning to live together... because the borders are no longer barriers but spaces for mutual relations and for constructing our collective memory." He also remembered the common memory of the heroes at the border who "died fighting against injustice".

To share spaces of post-national cosmopolitism does not mean to renounce Spanish or Portuguese citizenship. However, we must recognise the importance of the ethnic primordial Catalan, Basque, Galician, Andalusian, Scottish, Breton and Northern Portuguese identifications, which cannot be waived for many citizens, like Martin \& Pujadas (1999: 10) state. These primordial and ethnic identifications do not impede the demands of other transnational identifications. To- 
day it is very easy to be a Spanish and Portuguese citizen at the same time (with dual nationality), but it is not so easy to be a French and Spanish citizen. The socialist government of Zapatero recognised (through the "Law of Historic Memory") in 2008 the right to acquire Spanish nationality for descendants of the Spanish exiled up to the third generation, most of whom resided in France and Belgium. All this suggests that today there is a process of recovering national memories which contribute to the growth of transnationalism and of the spaces for cosmopolitism through the creation of transnational identities. Historical memories-like those about the Portuguese and Galician people exiled from both dictatorships-are today not irrelevant for forming the memory of ethnicity and nationalisms.

Recently, the Galician nationalist movement has been interested in recovering the memories of the exiled and the martyrs from the past Civil War of 1936, with special attention to martyrs on the Portuguese border, like the works of Mendez Ferrín show, who is one of the most important representatives of Galician nationalism, and the works of $\mathrm{Da}$ Cruz on the Portuguese border. These national memories of the exiled are very important for the Galician nationalist movement in order to form a common Galician-Northern Portuguese ethnicity and nationality. Let us not forget the importance of the Galician exile into America in the formation of the nationalist movement memory, the figure of Rodriguez Castelao being central to it as the most important exiled Galician martyr of Franco's dictatorship.

The Galician nationalist movement has evolved from the idea of attaining independence-in the 70s and 80s of the 20th century-to the concept of participating in a cosmopolitan federalism, under the acknowledgement of Galicia as an emergent transnationality which includes the North of Portugal in this Iberian Federal state project, like Castelao proposed at the beginning of this movement.

On other hand, there is no doubt that cultural spaces which, today, are promoting transnationalism in Europe (Erasmus programmes, cities of European culture, memories of the Nazi concentration fields, festivals on the culture of peace, festivals with Celtic roots), there are adequate spaces for dissolving sentiments of nationalist xenophobia. Transnational activities of cooperation and common memories amongst Galician and Northern Portuguese people serve today to dissolve the old contempt between Galician and Portuguese people in the past, when the borders were firmly in place to divide nations and popular sentiments. These transnational communities, as well as cosmopolitan nations, like any other community, can always be unfinished projects in democracy, as Augé (2010: 35) has said, but they constitute new projects for citizenships.

\section{Conclusion}

As I have suggested, we are arriving at the end of the absolutism of national sovereignties, at least in the advanced world. The ethnic processes affirmed within 
the states and transnationalism movements are emerging by reclaiming more cosmopolitan nations, as Giddens and others suggested. The creation of new public spheres, like the Euroregion between Galicia and Northern Portugal, constitutes new institutional opportunities for the ethnic affirmations and for developing transnational communities; yet they were not possible without the existence of transnational cultural movements, as we have seen. These movements are reconfiguring common memories, which are very important in the current Galician nationalist movement, the most interesting movement in favour of forming a Galician-Portuguese ethnicity.

I insisted on the anthropological concept of liminality, addressed in Victor Turner's work, for the formation of this transnational community in recent times, once democracy was constituted in Portugal and Spain. I think that similar experiences of transnational liminality could probably be important for developing cosmopolitism in other transnational contexts. The Galician-Northern Portuguese case shows that transnational citizenships demand their rights for constituting cultural transnational movements, which are the only transnational rights they can demand up to now.

However, citizenships, by affirming transnational communities, do not renounce their movements in favour of the formation of more ethnic communities every year. They are demanding the construction of the cosmopolitan nation. Fernandez (2010: 40) suggested that European states and their citizens are driving towards a new historical regeneration, which has nothing to do with the postcolonial regeneration, which was at the forefront of European history in the first 50 years of the 20th century, nor with the regeneration movement experienced in Spain from the colonial crisis of 1898, living the postcolonial nostalgia. Ethnic movements cannot live on by ignoring the transnationality of its citizens, neither state can live by ignoring its ethnic movements for their cultural regeneration.

\section{References}

Afonso, A. I. (2003) Borders of Memory: Images from a Portuguese-Spanish Village. In F. Branco, \& A. I. Afonso (Eds.), Rhetoric without Borders. Oeiras: Celta Publisher.

Appadurai, A. (1996). Modernity at Large. Cultural Dimensions of Globalization. Minneanapolis: Universsity of Minnesita Press.

Archibugi, D. E., \& Held, D. (2011). Cosmopolitan Democracy: Paths and Agents. Ethics \&International Affairs, 25, 433-461. https://doi.org/10.1057/9780230357075_2

Augé, M. (2010). The Illusory Community. Paris: Payot.

Barreiro Barreiro, J. L. (2016). Identities and Boundaries (Vol. 1). Santiago: The University of Santiago de Compostela.

Barth, F. (1969). Introduction. Ethnic Groups and Boundaries. In F. Barth (Ed.), The Social Organisation of Culture Difference (pp. 9-38). Bergen-Oslo: Universitets Forlaget.

Beramendi, J. (2008). Portugal in the Galician Program: 1840-1936. In X. Pereiro, L. Risco, \& C. Llana (Eds.), Boundaries and Border Identities between Portugal and Spain (pp. 13-28). Vila Real: Sector Editorial SDE. 
Bourdieu, P. (1990). The Logic of Practice. Cambridge: Polity Press.

Bourdieu, P. (1998). Practical Reason-On the Theory of Action. Stanford, CA: Stanford University Press.

Brubaker, R. (2009). Ethnicity, Race and Nationalism. Annual Review of Sociology, 35, 21-42. https://doi.org/10.1146/annurev-soc-070308-115916

Cabral, M. V. (1992). Portugal and Europe: Differences and Similarities. Journal Analise Social, 118-119, 943-954.

Da Cruz, B. (1980). The Warrior Wolf. Vigo: Xerais.

Diniz, F., \& Gerry, C. (2008). Cross-Border Strategies of Medium, Small, and Micro Business Sat the Border of Zamora and Tras-Os-Montes. In X. Pereiro, L. Risco, \& C. Llana (Eds.), Boundaries and Border Identities between Portugal and Spain (pp. 145-164). Vila Real: Sector Edit SDE.

Douglass, W. (1998). A Western Perspective on an Eastern Interpretation of Where North Meets South: Pyrenean Borderland Cultures. In Th. Wilson, \& H. Donnan (Eds.), Border Identities. Nation and State at International Frontiers (pp. 62-95). Cambridge: Cambridge University Press.

Douglass, W. (1999). Boundaries: Configuration of Mental and Physical Maps in the Pyrenees. In J. J. Pujadas, E. Martín, \& J. Pais de Brito (Eds.), Globalization, Cultural and Political Boundaries, and Citizenships (pp. 17-28). Santiago de Compostela, FAAEE-AGA.

Falagan, J., De Carlos, P., \& Lorenzo, P. (2013). Cross-Border Mobility of Workers between Galicia and the Northern Portugal. Journal Contabilidad \& Negocios, 15, 77-94.

Fernandez, J. W. (2010). About Nativism and National Identities in the Age of Globalization. Review Revistade Dialectología \& Tradiciones Populares, 65, 11-44.

Giddens, A. (1998). The Third Way: The Renewal of Social Democracy. Cambridge: Polity Press.

Godinho, P. (1995). The Smuggling as Astrategyin Border Villages of Tras-Os-Montes. Journal Trabe de Ouro, 2, 209-222.

Godinho, P. (2008). Social Groups and Cultures in Movement at the Border of Chaves, and Verín. In X. Pereiro, L. Risco, \& C. Llana (Eds.), Boundaries and Border Identities between Portugal and Spain (pp. 213-227). Vila Real, Sector Edit SDE.

Godinho, P. (2011). By Hearing to Sing a Cock Twice. Ourense: Diputación Provincial de Ourense.

Habermas, J. (2006). The Divided West. Cambridge: Polity Press.

Hannerz, U. (1990). Cosmopolitans and Locals in World Culture. In M. Featherstone (Ed.), Global Culture (pp. 237-251). London: Sage. https://doi.org/10.1177/026327690007002014

Hannerz, U. (2006) Two Faces of Cosmopolitanism: Culture and Politics. Barcelona: Cidob.

Held, D. (1995). Democracy and the Global Order. Cambridge: Polity Press.

Kavanagh, W. (1994). Symbolic and Real Boundaries in Borders of Spain and Portugal. In R. Sanmartín (Ed.), Anthropology without Boundaries (pp. 645-658). Madrid: CIS.

Kavanagh, W. (2011). Identities in the Spanish-Portuguese Borders after Schengen. Journal Geopolitica, 2, 23-50.

Kastoriano, R. (2000). Immigration, Transnational Communities and Citizenships. Journal Revue Internationale des Sciences Sociales, 165, 353-359.

Kuper, A. (1999). Culture, the Anthropologists' Account. Cambridge: Harvard University 
Press.

Kurlansky, M. (1998). Cod: A Biography of the Fish That Changed the World. Ebury: Vintage.

Leão, F. C. (1973). The Portuguese Enigma (2nd ed.). Lisboa: Guimarães Editores.

Lourenço, E. (1988). We and Europe, Two Reasons. Lisboa: Nacional Print.

Martin, E., \& Pujadas, J. J. (1999). Ethnic Mobility, Citizenships, Transnationalism and Boundaries. In J. J. Pujadas, E. Martín, \& J. Pais de Brito (Eds.), Globalization, Cultural and Political Boundaries, and Citizenships (pp. 7-16). Santiago de Compostela: FAAEE-AGA.

Martins, H. (2008). A Portuguese Village near Galice. Olhando de perto e de longeàsdiferenças e semellanças entre portugueses e galegos. In X. Pereiro, L. Risco, \& C. Llana (Eds.), Boundaries and Border Identities between Portugal and Spain (pp. 235-247). Vila Real: Sector Editorial SDE.

Medeiros, A. (2001). States and Traffics on Representation of Culture in North-Western of Iberia. In M. Cátedra (Ed.), The Crossed Glance in the Iberian Context (pp. 243-272). Madrid: Catarata.

Medeiros, A. (2013). Two Sides of One River, Nationalism and Ethnography in Galicia and Portugal. New York, NY: Berghan Books.

Mendez Ferrin, X. L. (1991). People on the Border. Vigo: Xerais.

Mendez, L. (2004) Galice in Europe. Santiago de Compostela: Ed. do Castro.

Moreno, I. (1991). Identities and Rituals. In J. Prat, U. Martínez, J. Contreras, \& I. Moreno (Eds.), Anthropology of the Spanish People (pp. 601-636). Madrid: Taurus.

Pardellas, X. (2006). The Construction of the Euro-Region between Galicia and Northern Portugal. In X. Pereiro, L. Risco, \& C. Llana (Eds.), Boundaries and Border Identities between Portugal and Spain (pp. 205-211). Vila Real: Sector Editorial dos SDE.

Pinto, J. F. (2007). The Psychological Factor for Affirming a Country like Portugal. Journal Res-Publica, Revista Lusofona de Ciencia Politica e Relações Internacionais, 5-6, 17-29.

Pascoaes, T. (1998). The Art of Being Portuguese. Lisboa: Assirio\&Alvim.

Pujadas, J. J., Comás, D., Moncusi, A., \& Martínez, C. (1999). Divided by Boundaries? Social and Economic Links between Spanish and French Cerdanya. In J. J. Pujadas, E. Martín, \& J. Pais de Brito (Eds.), Globalization, Cultural and Political Boundaries, and Citizenships (pp. 143-156). Santiago de Compostela: FAAEE-AGA.

Radcliffe-Brown, A. R. (1958). Method in Social Anthropology. Chicago: The University of Chicago Press.

Risco, V. (1920). The Sentiments of Landscape in the Galician Race. Journal Nos, 1, 4-9.

Rodríguez Campos, X. S. (2004). Paradoxes for Negotiating a Galician National Identity. Journal Quaderns del Institut Catala de Antropologia, 20, 81-104.

Rodríguez Castelao, A. (1976). Always in Galicia. Madrid: Akal.

Roigé, X. (2006). Identity, Boundaries and Tourism in the Valley of Aran. In J. Frigolé, \& $\mathrm{X}$. Roigé (Eds.), Globalization and Belonging, the Ethnographic Perspective (pp. 33-60). Barcelona: Ube.

Sahlins, P. (1989). The Making of France and Spain in the Pyrenees. San Diego: University of California Press.

Saramago, J. (2002). Journey to Portugal. London: Mariner Books.

Sobral, J. M. (2008). Race and Space in Interpretations of Portugal. The North-South Division and Representations of Portuguese National Identity in the Nineteenth and 
Twentieth Centuries. In Sh. R. Roseman, \& Sh. S. Parhurst (Eds.), Recasting Culture and Space in Iberian Contexts (pp. 205-224). State University of New York Press.

Shweder, R. A. (2010). Geertz's Challenge: Is It Possible to Be a Robust Cultural Pluralist and a Dedicated Political Liberal at the Same Time? In A. Sarat (Ed.), Law without Nations. Stanford, CA: Stanford University Press, 185-231. Hyperlink

https://humdev.uchicago.edu/sites/humdev.uchicago.edu/files/uploads/shweder/Geertz ChallengeShweder-1.pdf

Turner, V. (1969). The Ritual Process. Structure and Anti-Structure. Brunswick and London: Aldine Transaction.

Valcuence del Rio, J. M. (1998). Boundaries, Territories, and Collective Identities. Sevilla: Editions Blas Infante. 